\title{
Cattle Diets on Shortgrass Ranges with Different Amounts of Fourwing Saltbush
}

\author{
M.C. SHOOP, RICHARD C. CLARK, W.A. LAYCOCK, AND RICHARD M. HANSEN
}

\begin{abstract}
Inadequate data have existed concerning cattle preferences for fourwing saltbush [Atriplex canescens (Pursh) Nutt.] on ranges where it is dominant, and concerning composition of cattle diets on the central shortgrass plains. In this study, food habits of cattle were estimated from fecal analyses on winter and summer pastures containing either abundant or sparse fourwing saltbush (saltbush). The abundant saltbush was on overflow and/or sandy plains range sites; sparse saltbush was on loamy plains range sites. Saltbush was a major constituent of cattle diets where abundant. The proportion of saltbush in winter diets peaked during March (55\%) and declined during April. Saltbush was absent from summer diets during July, peaked during August (42\%), and declined abruptly during September. Where abundant, saltbush was also the primary constituent of the forb-shrub component of diets during both winter $(\bar{X}=72 \%)$ and summer $(\bar{X}=44 \%)$. Deleting saltbush from the data, cattle foods consumed on pastures with sparse and abundant saltbush were correlated ( 0.84 ) during summer, but were not correlated (0.25) during winter. Relative to species frequencies in pastures, cattle diets on loamy plains range sites (sparse saltbush) contained notably larger portions of sed ges (Carex spp. L.), goosefoots (Chenopodium spp. L.), and fringed sagewort (Artemisia frigida Willd.), during winter and goosefoots and scarlet globemallow [Sphaeralcea coccinea (Nutt.) Rydb.] during summer, than diets on sandy plains and overflow sites (abundant saltbush). Saltbush is a preferred and valuable forage for cattle on the central shortgrass plains, and it should be managed to maintain or improves its productivity.
\end{abstract}

Fourwing saltbush [Atriplex canescens (Pursh) Nutt.] is one of the most widely distributed, highly palatable, and nutritious browse species in the western United States (Bidwell and Wooten 1925, Plummer et al. 1966, Pieper and Donart 1978). However, little quantitative data exist pertaining to cattle diets in areas where fourwing saltbush (saltbush) is abundant. Cattle dietary habits are complex, and are affected primarily by relative availability and palatability of foods. Traditionally, cattle have been classified as general grazers, primarily ingesting grasses while utilizing forbs and browse only occasionally or in stress situations (Cook et al. 1967, Lesperance et al. 1970, Allison et al. 1977). A number of cattle dietary studies have emphasized the importance and potential of certain forb and browse species as cattle foods (Cully 1937, Herbel and Nelson 1966, Thetford et. al. 1971, Rosiere et al. 1975, Vavra et al. 1977).

Saltbush provides relatively large amounts of essential nutrients, including protein, phosphorus, calcium, and carotene, even during winter months (Bidwell and Wooten 1925, Watkins 1943, Cook and Harris 1968, Pieper et al. 1959, Sims and Taylor 1973, Cordova and Wallace 1975, Cook et al. 1977). The digestibility of saltbush often compares favorably with that of grasses, forbs, and

\footnotetext{
At the time of research, Shoop and Laycock were range scientists, USDA, ARS Forage, Range, and Livestock Management Investigations, Crops Research Laboratory, Colorado State University, Fort Collins 80523; Clark and Hansen were research associate and professor, respectively, Department of Range Science, Colorado State University, Fort Collins 80523. The current address of Clark is 532 University Ave., Roulder, Colo. 80302

This article is the result of cooperative investigations of the USDA, Agricultural Research Service, and Colorado State University. Experiment Station. Colorado State University Scientific Series Paper No. 2870.

Manuscript accepted January 28, 1985.
}

other shrubs (Pieper et al. 1959, Cook and Harris 1968, Sims and Taylor 1973, Cordova and Wallace 1975), but its digestibility during dormancy may not compare well with that of grasses under some situations (Sims and Taylor 1973).

On ranges where abundant, saltbush should ameliorate forage shortages, e.g., during droughts and snow covers (Foster et al. 1921, Plummer et al. 1966, Pieper and Donart 1978). By adding species diversity, saltbush should improve the quality of cattle diets (Herbel and Nelson 1966, Plummer et al. 1966, Cook and Harris 1968, Pieper and Donart 1978).

Saltbush has other noteworthy attributes. It provides a microenvironment where other species can produce more herbage and protein and can become established and survive more successfully than in its absence (Monsen 1980, Rumbaugh et al. 1982, Laycock and Shoop unpublished data). Fairchild and Brotherson (1980) reported greater levels of some minerals beneath saltbush plants than between them. Saltbush has been reported as a secondary or facultative selenium accumulator (Fleming 1920), and perhaps it could accumulate toxic levels of selenium from depths below roots of associated species (Foster et al. 1921).

Data are lacking or inadequate for cattle dietary preferences on shortgrass range in the Central Plains relative to winter-use, sandy plains or overflow range sites, summerlong grazing, or moderately grazed pastures. The most comprehensive of the earlier studies reported esophageal and fecal data collected during June through August of 2 years and December of 1 year from heavily and lightly grazed summer pastures at the Central Plains Experimental Range (CPER) (Rice and Vavra 1970, Vavra et al. 1977, Vavra et al. 1978). These studies were conducted in pastures primarily on a loamy plains site, but that included a small, plains swale site that produced considerable western wheatgrass (See Table 1 for Latin names of species). Kautz and Van Dyne (1978) used the foregoing studies and a limited amount of associated data to report mean percentage consumption of each species detected in diet samples. Hansen and Gold (1977) reported mean seasonal dietary composition of a limited number of species at CPER as determined from fecal samples collected intermittently from various range sites, some of which included revegetated abandoned cropland. Quinton (1972) reported 2 years of data for 6 plant species and categories on 2 pastures on a loamy plains range site near Akron, Colo.

The primary objective of this study was to determine the importance of saltbush relative to other forages in the diets of cattle on winter and summer pastures on the central shortgrass plains. A secondary objective was to help characterize cattle diets on the shortgrass range of northcentral Colorado, especially for winter pastures and summer pastures on sandy plains range sites.

\section{Methods}

This study was conducted about $15 \mathrm{~km}$ northeast of Nunn, Colo., on the CPER where saltbush is abundant on overflow and sandy plains range sites, but is sparse or nonexistent on loamy range sites (Hyder et al. 1966). Blue grama is the dominant grass. Other important species on the sites are listed in Table 1.

During the 1976-77 forage year, April through September precipitation was $96 \%$ of the long-term average of $25.0 \mathrm{~cm}$; October through April precipitation was $\mathbf{9 0 \%}$ of the long-term average of 
Table 1. Species frequency in pastures and species composition in cattle feces collected during five periods of 1976-77 from continuously grazed winter pastures with abundant and sparse fourwing saltbush.

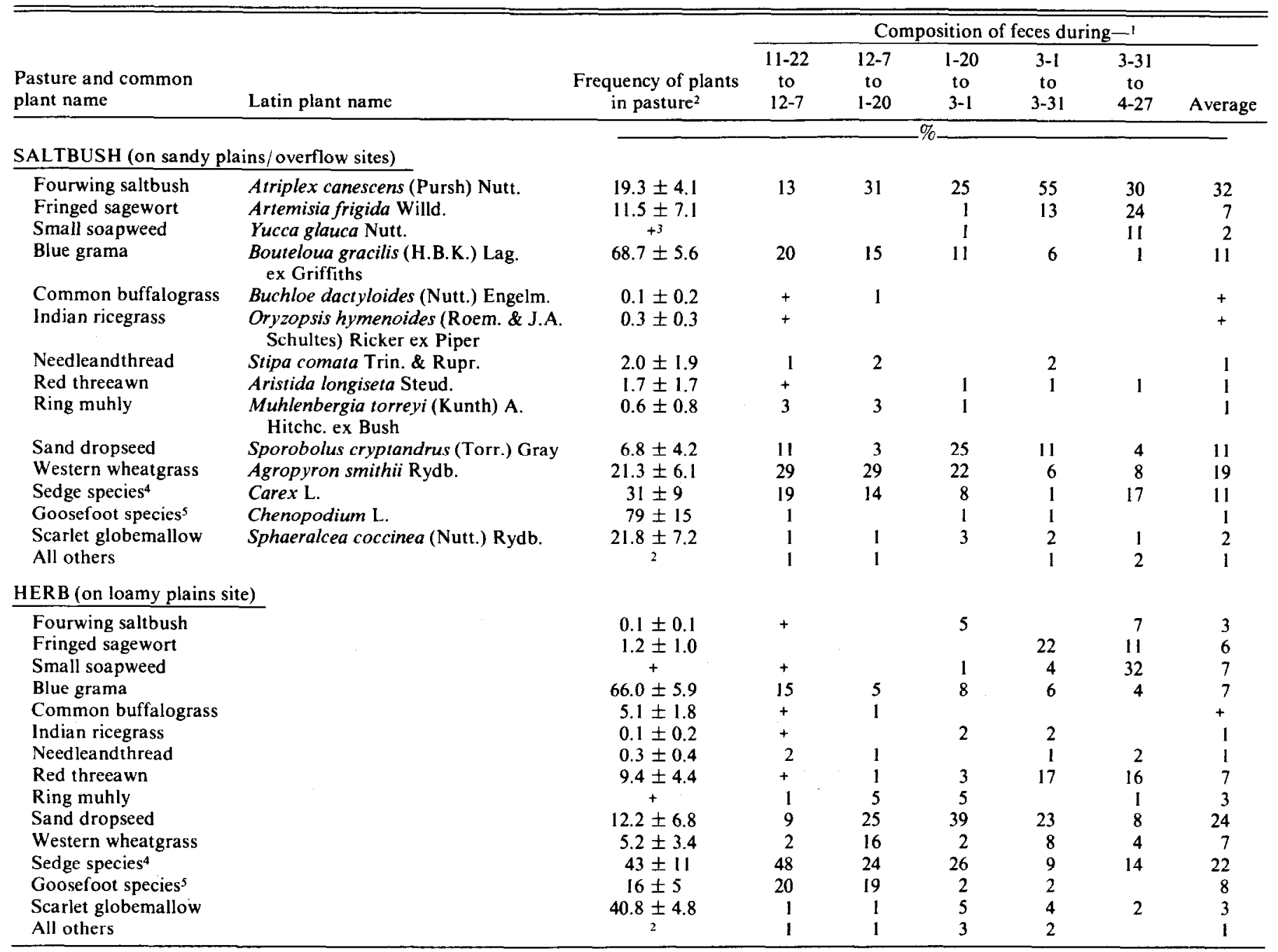

Columns may not add to $100 \%$ because of rounding of numbers. Averages are weighted according to days in periods.

${ }^{2}$ Frequencies $(\%)$ of other noteworthy species in salthush and herb pastures, respectively, were: broom snakeweed [Gutierrezia sarothrae (Pursh) Britton and Rusby, also Xanthocephalum sarothrae] 0.3. 3.8: rubber rabbitbrush [Chrysothamnus nauseosus (Pallas ex Pursh) Britton] 0.8. 1.1; spreading wildbuckwheat (Eriogonum effusum Nutt.) 7.8. 2.8; bottlebrush squirreltail [ Sitanion hystrix (Nutt.) J.G. Smith] 0.3, 0.9; common russianthistle (Salsola pestifer A. Nels.) 9.8, 6.8; and plains pricklypear (Opuntio polyacantha Haw.) 20.1, 25.5.

${ }^{3}+=$ present at $<0.5 \%$; or present but not encountered in frequency survey.

${ }^{4}$ Approximate composite frequency for threadleaf sedge (Carex filifolia Nutt.) and needleleaf sedge [C. stenophylla Wahlenb. ssp. eleocharis (L.H. Bailey) Hulten, sometimes reported from this location as sun sedge (C. heliophila Mackenz.)].

${ }_{5}$ Approximate composite frequency for lambsquarter goosefoot (Chenopodium album L.), little goosefoot [C. incanum S. Wats.) A. Helier], and narrowleaf goosefoot [C. leptophyllum (Moq.) Nutt. ex S. Wats.).

$8.4 \mathrm{~cm}$; and snowfall was typically sparse until late winter. Precipitation during the summer of 1977 was $84 \%$ of average with August and September having only $24 \%$ of the average precipitation. Annual forbs were abundant both years.

Diets of cattle on pastures with different amounts of saltbush were compared. Concomitantly, diets on different range sites were also compared. Separate trials were conducted on seasonal pastures grazed winterlong and summerlong. Each pasture contained $64 \mathrm{ha}$ and was stocked to leave a herbage residue of about 340 $\mathrm{kg} / \mathrm{ha}$ at the end of the grazing season. Bement (1969) found this residue level sustained optimum cattle gains and herbage production.

The winter and summer trials were each conducted on 2 pastures. In each trial, saltbush was abundant on one pasture (saltbush pasture) and sparse on the other (herb pasture, Tables 1 and 2).

Each winter pasture had about $520 \mathrm{~kg}$ of grass per hectare and an undetermined amount of forbs and browse at the start of grazing.
Yearling heifers (initially 18 to 20 months of age) were introduced in November 1976 and remained until the end of April 1977. The saltbush pasture (located on sandy plains and overflow range sites) was stocked with 10 heifers, and the herb pasture (located on a loamy plains range site) was stocked with 8 heifers on the basis of grass inventories and estimated amount of feed available from forbs and shrubs. The leaves of saltbush had been freeze-killed, and about 30 to $40 \%$ of the fruit had been shed by the time the cattle entered the pastures. Herbage residue when the cattle were removed from the pastures was about $350 \mathrm{~kg} / \mathrm{ha}$.

In the summer trial, yearling cattle (initially 13 to 15 months of age) were introduced in June 1977 and remained until October 1977. The saltbush pasture (sandy plains) was stocked with 12 head, and the herb pasture (loamy plains) was stocked with 9 head. Summerlong forage production was not measured. In midOctober, herbage residue was estimated to be 320 and $305 \mathrm{~kg} / \mathrm{ha}$ on 
the 2 respective pastures. The amounts of herbage residue and cattle gains both indicated slightly heavier than moderate grazing intensities (Bement 1969).

Consumption of plant species by cattle was estimated by fecal analyses. Fecal samples of approximately $2 \mathrm{~g}$ were collected at intervals of 4 to 6 weeks from 20 cattle defecations chosen randomly from a site near the water tank in each pasture. Sample sites were cleaned of all cattle feces following each collection. Fecal samples within each sample period and pasture were composited.

Plant species in feces were identified and quantified microscopically using procedures described by Sparks and Malechek (1968). Five slides were made of each composited sample, and 20 microscopic ficlds were examined per slide for a total of 100 microscopic fields per pasture for each sampling period. Identification of plant fragments was carried out by R.C. Clark (who had 4 years of experience identifying species fragments, high accuracy quantifying species in mixtures of known composition, and experience with especially difficult-to-identify species). Independent identification of species on randomly selected slides by an experienced observer did not differ from those made for the study $(P>0.05)$.

The percentage of classified plant species fragments in feces has been widely used to quantify herbivore diets even though the dry weight fractions of certain plant species may be slightly over- or under-estimated by the fecal analysis technique (Hansen et al. 1973, Takatsuki 1978, McInnis et al. 1983, Johnson et al. 1983). The age of feces when sampled (from 0 to 6 weeks of age) also may have influenced estimates of diet composition in this study. A study by B.E. Dahl (personal communication) indicated that cattle feces 1 or 2 days old showed a greater proportion of easily digested specics than feces 2 to 3 weeks old. Thus, it is probable that percentage composition of some species in this study, especially forbs, was under-estimated and that of other species, especially grasses, was over-estimated.

Orders of abundance of food items in cattle feces were compared by using Spearman's rank correlation coefficient (RHO). Correlation of ranks was assumed to estimate the between-pasture degree of similarity (+ value) or dissimilarity ( value) of the plant species in the cattle feces. Probability levels were assumed to be significant at the 0.05 level of confidence.

Abundance of plant species in pastures was obtained by frequency sampling (Hyder et al. 1966) during late July to serve as an index of the quantity of each species available to cattle. Plant frequencies are usable indices of forage availability primarily within a species or among species with similar forms and patterns of growth. In each pasture, 25 macroplots were established in a restricted random fashion so that each 2.6 ha contained a macroplot. Each macroplot was a sampling unit and consisted of three 23-m transect lines spaced at 5-m intervals. Each transect line had 25 quadrats spaced at $91-\mathrm{cm}$ intervals. Quadrats for blue grama were 5.1-cm squares nested within the $40.6-\mathrm{cm}$ squares used for all other species.

Latin plant names used were usually those listed by the USDASCS (1982). Range sites used were the drier phases of these described by the USDA-SCS, Colorado (1975-1983). Soil information, which is too extensive to include here, is available from M.C. Shoop.

\section{Results and Discussion}

\section{Winter Trial}

Six plant species comprised $90 \%$ of the diet of cattle on the winter saltbush pasture on the sandy plains/ overflow sites (Table 1). Saltbush was the major forage selected. The other 5 major plant species $(X \geq 5 \%)$ in the diet, in ranked order, were: western wheatgrass, sand dropseed, sedges, blue grama, and fringed sagewort.

Eight forages accounted for an average of $88 \%$ of the species selected by cattle on the winter herb pasture on the loamy plains site (Table 1). The 8 major forages, in ranked order, were: sand dropseed, sedges, goosefoots (primarily narrowleaf goosefoot), western wheatgrass, red threeawn, blue grama, small soapweed, and fringed sagewort.

The orders of abundance of cattle foods in the diets from the 2 winter pastures were not correlated $(\mathrm{RHO}=+0.10)$. The correlation coefficient $(\mathrm{RHO}=+\mathbf{0 . 2 5})$ increased only slightly when saltbush was deleted from the data. These low diet correlations were caused by the differences in species abundance and species eaten. The coefficient of community similarity (Spatz 1970) between pastures (calculated for the frequencies of those species in the diets except saltbush) was only $39 \%$. Cattle in the 2 pastures ate different amounts of fringed sagewort, small soapweed, sedges, and goosefoots, relative to the frequencies of each species in the pasture.

\section{Summer Trial}

Seven forage taxa comprised $84 \%$ of the diets of cattle on the summer saltbush pasture on the sandy plains site (Table 2). These were, in ranked order: sand dropseed, western wheatgrass, saltbush, blue grama, goosefoots, sedges, and scarlet globemallow. Saltbush was moderately abundant in the pasture ( $8 \%$ frequency), although it was less abundant than in the comparable winter pasture.

Six forage taxa accounted for $82 \%$ of the summer cattle diets from the herb pasture on the loamy plains sites. These were, in ranked order: blue grama, sand dropseed, goosefoots, sedges, scarlet globemallow, and western wheatgrass.

The orders of abundance of cattle foods in the diets from the 2 summer pastures were not correlated $(\mathrm{RHO}=+0.51)$. However, when the saltbush data were deleted, the diets were correlated ( $\mathrm{RHO}=+0.84$ ), indicating that cattle were selecting similar foods in both pastures independently of the presence of saltbush. The latter diet correlation was surprisingly high considering that the coefficient of community similarity was only $38 \%$ for the species in the diet other than saltbush, and considering that although the winter pastures had a similar coefficient of community similarity (39\%), their diets were not correlated. Cattle in the herb pasture ate more red threeawn, western wheatgrass, goosefoots, and scarlet globemallow and less sedges than cattle in the saltbush pasture, relative to the plant frequencies.

\section{Both Trials}

Saltbush was a major component of cattle diets $(\bar{X} \sim 23 \%)$ on both winter and summer saltbush pastures. It was consistently a major food during winter months, reaching peak consumption during March when it comprised 55\% of the diet, and declining in early spring to near its seasonal average of $32 \%$ (Table 1 ). Percentage composition of saltbush in diets varied greatly during summer months, most notably falling to none during July, peaking abruptly during August (42\%), and falling abruptly during September $(13 \%)$ (Table 2). The authors found no other data concerning within-season time of cattle grazing of saltbush on range where it was dominant. On pinyon-juniper range in New Mexico, where it was sparse, it appeared in diets in January, April, June, and October (Thetford et al. 1971). Pfister et al. (1984) indicated that on year-long shortgrass range in New Mexico having a small amount of fourwing saltbush, consumption of saltbush peaked at near $23 \%$ of the diet in late June, but became a minor dietary constituent later in the summer.

Fringed sagewort was an important food during winter, but of minor importance during summer. Cattle on winter pastures ate sagewort primarily during March and April. Consumption of sagewort increased as more preferred species became less available, a trend in forage selection observed in several other studies of species preferences (Doran 1943, Springfield and Reynolds 1951, Pieper et al. 1959). Cattle may have eaten more sagewort than normal during March and April, especially on the loamy plains site, when snow depth was about $18,2,4,1$, and $13 \mathrm{~cm}$ from 5 separate snowfalls. Reppert (1960) reported increased consumption of sand sagebrush (Artemisia filifolia Torr.) when snow covered short vegetation. Rice and Vavra (1970) observed $21 \%$ 
Table 2. Species frequency in pastures and species composition in cattle feces collected during four periods of 1977 from continuously grazed summer pastures with abundant and sparse fourwing saltbush.

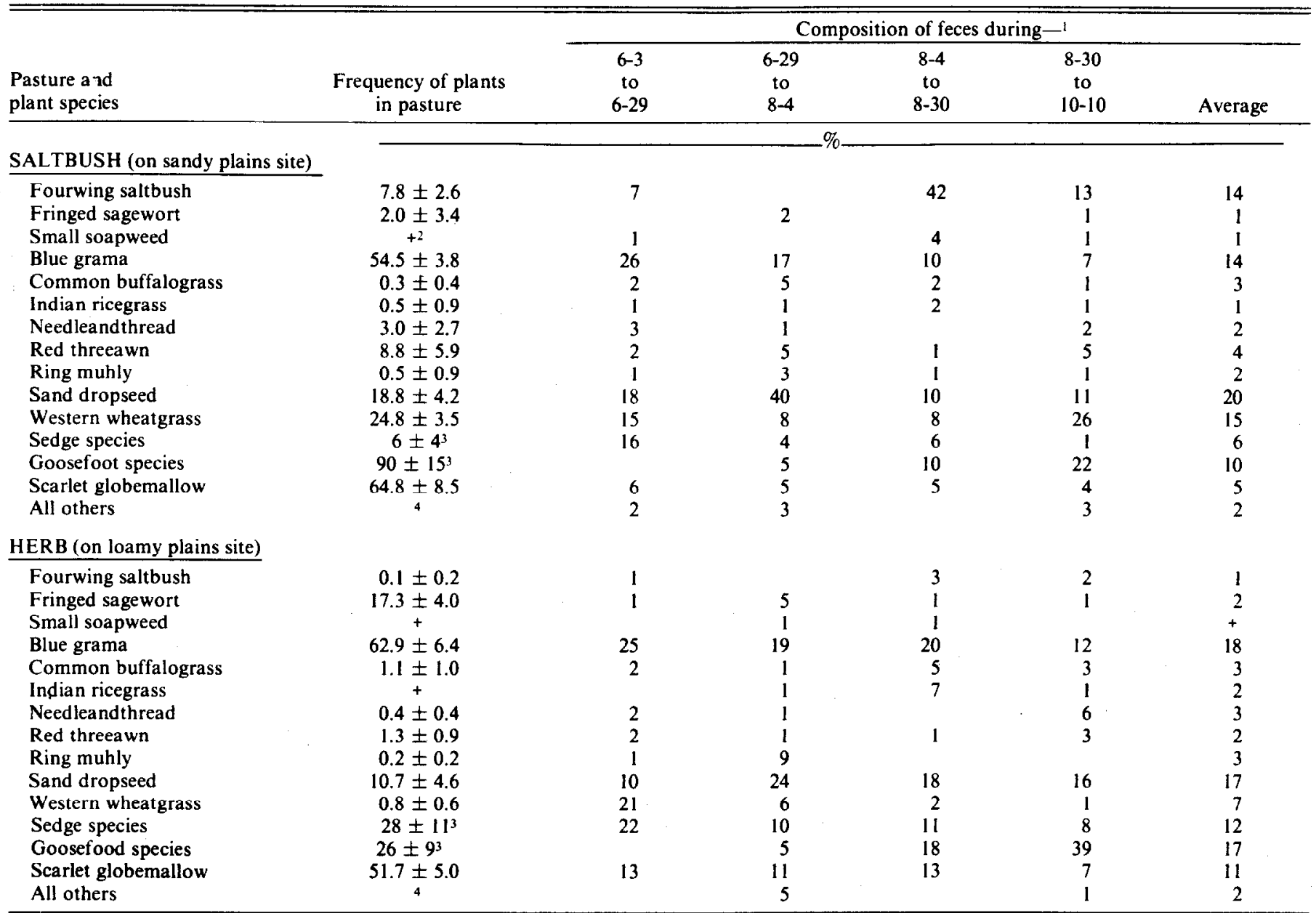

Columns may not add to $100 \%$ because of rounding of numbers. Averages are weighted according to days in periods.

$2+=<0.5 \%$ : or present but not encountered in frequency survey.

${ }^{3}$ Approximate average for 2 sedges or 3 goosefoots.

${ }_{4}^{4}$ Frequencies $(\%)$ of selected other species in saltbush and herb pastures, respectively, were broom snakeweed $0.8,0.3 ;$ rubber rabbitbrush $0.3,0.1 ;$ spreading wildbuckwheat 29.0 , 6.2 ; bottlebrush squirreltail $0.5,0.1$; common russianthistle $10.0,6.2$; and plains pricklypear $50.8,33.2$.

sagewort in dietary samples collected during December from a lightly grazed summer pasture, but the cattle may not have been completely adapted to the pasture. Summer consumption of sagewort peaked at low levels during July. Vavra et al. (1977) reported greater consumption of sagewort on nearby herb pastures (loamy plains) during August than during June or July, and a June through August consumption similar to that on the loamy plains site in this study (Table 3). Klipple and Costello (1960) reported only $15 \%$ utilization of sagewort on summer pastures at CPER where blue grama utilization was $63 \%$. Small amounts of sagewort appear to be an asset on shortgrass range, especially on loamy plains sites and on winter range.

Consumption of small soapweed was appreciable during April, especially on the loamy plains site (Table 2). Also, consumption of soapweed was notable during August on the sandy plains site, where it was relatively more abundant, because of the inclusion of a small, break site in the pasture, than on the loamy plains site (Table 2). Although relatively abundant in a few small areas, soapweed overall had a low frequency on the pastures. Thus, cattle showed a pronounced preference for small soapweed during late winter and August. Cattle on many ranges have ingested leaves of soapweed species during late winter and inflorescences during summer (Reppert 1960, Herbel and Nelson 1966, Rosiere et al. 1975). In small quantities, soapweed is a desirable component of the species com position on shortgrass range.

Plains pricklypear was eaten sparingly only during early winter. Maximum consumption was on the saltbush pasture during December-January (1.2\% of the diet). Kautz and Van Dyne (1978) are the only researchers for the area to have reported plains pricklypear in diets $(0.1 \%)$, although cattle have been observed to eat it when moisture made the spines lax at the base (Hyder et al. 1975).

Although available in appreciable amounts, broom snakeweed, rubber rabbitbrush, and speading wildbuckwheat were never present in diets in significant amounts ( $<2 \%$ in any sample). Vavra et al. (1977) reported that spreading wildbuckwheat constituted about $8 \%$ of diets during July and August on CPER loamy range, where it was more abundant than in this study area and where 1 of the 2 pastures was heavily grazed. Kautz and Van Dyne (1978) reported diets on CPER containing nearly $2 \%$ broom snakeweed and about $0.5 \%$ rubber rabbitbrush. Klipple and Costello (1960) found that utilization of broom snakeweed and rubber rabbitbrush on summer range rose sharply to about $20 \%$ when utilization of blue grama reached $46 \%$ and $56 \%$, respectively for the 2 shrubs.

Compared to their frequencies in the pastures, large quantities of sand dropseed and small quantities of blue grama were consumed (Tables 1 and 2). However, the amount of a species selected by livestock is sometimes greatly disproportionate to the amounts of it available (Heady and Torell 1959). Also, frequency is only a 
Table 3. Proportions of species in diets observed in various studies with yearling cattle grazing on the Central Plains Experimental Range during three periods.'

\begin{tabular}{|c|c|c|c|c|c|c|c|}
\hline \multirow[b]{2}{*}{ Plant species } & \multicolumn{3}{|c|}{ June through August } & \multicolumn{2}{|c|}{ December $^{2}$} & \multicolumn{2}{|c|}{ December through March } \\
\hline & $\begin{array}{l}\text { This } \\
\text { study }\end{array}$ & $\begin{array}{l}\text { Vavra } \\
\text { et al. } \\
1977\end{array}$ & $\begin{array}{c}\text { Hanson } \\
\& \text { Gold } \\
1977\end{array}$ & $\begin{array}{l}\text { This } \\
\text { study }\end{array}$ & $\begin{array}{c}\text { Rice } \& \\
\text { Vavra } \\
1970\end{array}$ & $\begin{array}{l}\text { This } \\
\text { study }\end{array}$ & $\begin{array}{c}\text { Hansen } \\
\& \text { Gold } \\
1977\end{array}$ \\
\hline & & & & $-\%$ & & & \\
\hline Fringed sagewort & 3 & 2 & & & 21 & 5 & \\
\hline Spreading wildbuckwheat & & 5 & & & & & \\
\hline Total shrubs & 5 & & & $<1$ & & 8 & \\
\hline Blue grama & 21 & 38 & 12 & 5 & 52 & 7 & 12 \\
\hline Common buffalograss & 2 & 2 & 3 & 1 & & $<1$ & 1 \\
\hline Needleandthread & 1 & 4 & 3 & $i$ & & 1 & 4 \\
\hline Red threeawn & 1 & 4 & & 1 & 3 & 5 & \\
\hline Sand dropseed & 18 & $<1$ & 10 & 25 & & 27 & 13 \\
\hline Western wheatgrass & 9 & 8 & 23 & 16 & & 8 & 43 \\
\hline Sedge species & 14 & $9^{3}$ & 25 & 24 & 16 & 24 & 15 \\
\hline Total, above graminoids & 66 & 65 & 76 & 73 & 71 & 72 & 88 \\
\hline Total, all graminoids & 75 & 65 & & 79 & 74 & 79 & \\
\hline Scarlet globemallow & 12 & 13 & 11 & 1 & 2 & 3 & 2 \\
\hline Total forbs & 20 & & & 21 & 4 & 13 & \\
\hline Total forbs-shrubs & 25 & 35 & & 21 & 26 & 21 & \\
\hline
\end{tabular}

'Each study was conducted prima rily on a loamy plains range site, but the study of Hansen and Gold (1977) also included data from other nonspecified sites. Categories of data may not add to stated sums because of rounding of data. Where amount of a summary category was not indicated, it was not ascertainable from the report.

2Data were for period 12-7 to 1-20. Data of Rice and Vavra (1970) was from a pasture that had been lightly summer grazed since 1939.

. Needleleaf sedge, only.

general indicator of species availability. In this study, consumption of blue grama on the loamy range site during June through September was about $45 \%$ lower than that reported by Vavra et al. (1977), but it was 75\% greater than that reported by Hansen and Gold (1977) (Table 3). Hansen and Gold (1977) also found about $70 \%$ more blue grama consumption during winter than occurred in this study. Relative to amounts of sand dropseed observed in diets of this study, Vavra et al. (1977) reported much less consumption during June through August $(\vec{X}<1 \%)$; and Hansen and Gold (1977) reported about one-half as much consumption during summer and winter (Table 3). More research is needed to understand the relative amounts of blue grama and sand dropseed consumed by cattle on these ranges and the situations that influence the relative proportion of the 2 species.

Red threeawn provided food primarily during late winter on the loamy plains site, where it was relatively abundant. Data were not collected during May, when red threeawn made its early growth and should have been least coarse. Its pattern of consumption was similar to that of sagewort: It probably was consumed primarily when more preferred forages were scarce, and it may have provided cattle on the loamy plains site with forage during March and April following snows. Most red threeawn herbage remains ungrazed at the end of the forage year on shortgrass range (Klipple and Costello 1960, Hyder et al. 1975). Thus, shortgrass range should be managed to minimize the amount of threeawn in the species composition (Hyder et al. 1975).

Results from this and other studies in the area confirm that western wheatgrass is a preferred cattle forage, especially during spring and fall when it makes most of its growth (Quinton 1972, Hansen and Gold 1977, Vavra et al. 1977, Kautz and Van Dyne 1978). Ranges well adapted to western wheatgrass usually should be managed to maintain productive stands. However, in the drier half of the shortgrass plains, where little spring and fall precipitation is received, western wheatgrass is usually adapted and productive only on soils with high permeability or where moisture is received from other areas or sources (Hyder et al. 1966, Hyder et al. 1975).

The sedges were important in winter and summer diets, especially on loamy plains sites where they were more abundant than on sandy plains/ overflow sites. They were eaten primarily during the November-December period when the cattle first entered the pastures, after which consumption declined until April, then increased appreciably. Consumption of sedges generally declined summer-long from the peak consumption during June. Sedges are a preferred species during early spring when they provide forage before other species have edible new growth (Hansen and Gold 1977; Shoop, unpublished data). More sedges were consumed on loamy plains during June through August in this study than Vavra et al. (1977) found at CPER; sedge consumption was about $60 \%$ less than Hansen and Gold (1977) reported for nonspecified sites on CPER (Table 3). Sedges, in moderate stands, are valuable forages on shortgrass range, but Hyder et al. (1975) reported that needleleaf sedge was nonresponsive to nitrogen fertilizer or to month of repeated heavy grazing.

The goosefoots (about $90 \%$ narrowleaf goosefoot) were a surprisingly large component of cattle diets. Hyder et al. (1975) reported May and June to be about the only months when cattle could be forced to graze narrowleaf goosefoot when different pastures were heavily grazed during each of the 12 months. Streeter et al. (1968) reported that Chenopodium pratericola (apparently narrowleaf goosefoot, USDA-SCS 1982) constituted over $30 \%$ of esophageal samples collected from sandy range in western Nebraska during June and early July, about $47 \%$ at the end of July, and about 15\% during late August. In comparison, this study found goosefoots in fecal samples rising progressively on both pastures from about $0 \%$ during June to about $30 \%$ during September. The goosefoots were one of the 3 most eaten species on the loamy range site during early winter.

Scarlet globemallow was a minor component of winter diets as Rice and Vavra (1970) and Hansen and Gold (1977) found on other pastures at CPER. During summer, it consistently was one of the 5 most prevalent species in diets on the loamy plains site; it was a minor species in diets on the sandy plains site at all times. Average consumptions of scarlet globemallow during June through August on loamy plains were similar to that observed nearby by Vavra et al. (1977). The latter authors reported nearly twice as much of it in diets during July as during June and August; in this study consumption of scarlet globemallow was rather static during those months. Research on methods to increase production of scarlet globemallow seems warranted (Hyder et al. 1975).

Common russianthistle has been considered a desirable forage at CPER, especially during late summer and fall after grasses have matured (Klipple and Costello 1960, Hyder et al. 1975). Consequently, we were surprised that russianthistle constituted less than 
$2 \%$ of the diets during all sampling periods. These conflicting results may indicate that consumption of russianthistle varies among years and seasons. Possibly russianthistle was not detected in diets because of an artifact of the technique used, although the relatively low digestibly of russianthistle would seem to ensure its presence in the feces if consumed (Cave et al. 1936, Vavra et al. 1978, Vavra and Holechek 1980, McInnis et al. 1983, Johnson et a. 1983). Rosiere et al. (1975) reported that russianthistle was not always identified in esophageal samples even though it was being grazed during the general sampling period.

In both winter and summer pastures, graminoids constituted the bulk of diets during early months of the grazing season. As the season advanced, and the more preferred graminoids were increasingly utilized, cattle more readily ingested such shrubs, forbs, and less preferred grasses, as fringed sagewort, goosefoots (during summer), and red threeawn (Tables 2 and 3). Others have also noted that cattle increase consumption of less preferred species as more preferred species become increasingly scarce (Doran 1943, Springfield and Reynolds 1951, Pieper et al. 1959). Nevertheless the appreciable consumptions of saltbush on sandy plains/overflow sites during both winter and summer, and of goosefoots on the loamy plains during early winter, indicated that these species were relatively preferred at those times. Saltbush was more preferred than goosefoots throughout winter because cattle on the sandy plains/overflow sites never ate an appreciable amount of goosefoots, whereas, cattle on loamy plains sites did.

During at least 1 period of the grazing season, shrubs constituted a major portion of dietary composition on both of the winter pastures and on the summer saltbush pasture (period maximums = 46 to $69 \%$ ). Forbs also contributed appreciably to dietary composition during at least 1 period on both of the summer pastures and on the winter herb pasture (period maximums $=21$ to $47 \%$ ). Shrubs and forbs collectively constituted at least one-third of the diet during at least 2 periods on each of the 4 pastures.

\section{Conclusions}

Cattle on the central shortgrass plains eat appreciable amounts of saltbush when it is available, especially during winter. Thus, saltbush adds to the total feed supply and to the species diversity from which cattle can select to maintain a high level of nutrition.

Shortgrass ranges with abundant saltbush, primarily sandy plains and overflow sites, appear to be better suited for winter cattle range than sites with sparse saltbush, primarily loamy plains (Foster et al. 1921, Cook et al. 1977). By consuming a full ration consisting of $33 \%$ saltbush (the average in this study) and $67 \%$ blue grama, a dry, pregnant cow on winter range should receive an adequate intake of carotene and metabolizable energy, about $90 \%$ of needed crude protein, and about $60 \%$ of needed phosphorus (Cook et al. 1977, NRC 1984). In contrast, a comparable cow eating only blue grama would receive about $25,100,50$, and $60 \%$ of her needs for the respective nutrients.

Good stands of saltbush should be managed to maintain their productivty (Foster et al. 1921, Cook et al. 1977). Moderate winter grazing of saltbush on shortgrass range maintains denser and more productive stands than summer or year-long grazing (Pieper and Donart 1978, Shoop unpublished data). Trlica et al. (1977) and Buwai and Trlica (1977) found that saltbush plants produced less herbage and shorter seedstalks and twigs following defoliation while growing, especially while setting seed, than following defoliation while quiescent. Saltbush stands grazed while growing should be rested periodically, especially when defoliation is during late summer and early fall or is heavy (Klipple and Costello 1960, Trlica et al. 1977, Buwai and Trlica 1977, Pieper and Donart 1978). Consideration also should be given to re-establishing saltbush on sites where it is well adapted.

The contribution of shrubs and half-shrubs to cattle diets varies with inherent qualities of the individual species on a location and with factors specific to a situation, such as succulence and abun- dance of the species. In this study, saltbush, fringed sagewort, and small soapweed each provided appreciable portions of diets; rubber rabbitbrush and spreading wildbuckwheat never contributed to diets. Others also have reported that some shrubs furnish appreciable amounts of food while others furnished little or none (Herbel and Nelson 1966, Cook and Harris 1968, Lesperance et al. 1970, Thetford et al. 1971).

Despite lack of agreement among researchers about cattle peference for blue grama on the central shortgrass plains, all data indicate blue grama provides a sizeable portion of diets. It is especially well adapted to the climate of the central shortgrass plains (Hyder et al. 1975), probably more so than any other important grass. Consequently, blue grama should be a major species for composition goals of management and for mixtures of native seed used to revegetate land.

Western wheatgrass is a species highly preferred by cattle. It is best adapted to the same sites as saltbush, and also to wetter sites, and should be managed for optimum production of those sites. Sedges are a valuable adjunct to shortgrass range species, especially on loamy plains range sites. Small soapweed, fringed sagewort, and goosefoots contributed to cattle diets during some periods; small amounts of these species in pastures are desirable. Red threeawn is not a preferred species for cattle and should be managed against, especially on summer pastures.

\section{Literature Cited}

Allison, C.D., R.D. Pieper, G.B. Donart, and J.D. Wallace. 1977. Fertilization influences cattle diets on blue grama range during drought. $J$. Range Manage. 30:177-180.

Bement, R.E. 1969. A stocking-rate guide for beef production on blue grama range. J. Range Manage. 22:83-86.

Bidwell, G.L., and E.O. Wooten. 1925. Saltbushes and their allies in the United States. USDA Bull. 1345.

Buwai, M., and M.J. Trlica. 1977. Multiple defoliation effects on herbage yields, vigor, and total nonstructural carbohydrates of five range species. J. Range Manage. 30:164-171.

Cave, H.W., W.H. Riddell, and J.S. Hughes. 1936. The digestibility and feeding value of russian thistle hay. J. Dairy Sci. 19:285-290.

Cook, C.W., R.D. Child, and L.L. Larson. 1977. Digestible protein in range forages as an index to nutrient content and animal response. Range Sci. Dep. Sci. Ser. No. 29. Colorado State Univ., Fort Collins.

Cook, C.W., and L.E. Harris. 1968. Nutritive value of seasonal ranges. Utah Agr. Exp. Sta. Bull. 472.

Cook, C.W., L.E. Harris, and M.C. Young. 1967. Botanical and nutritive content of diets of cattle and sheep under single and common use on mountain range. J. Anim. Sci. 26:1169-1174.

Cordova, F.J., and J. Wallace. 1975. Nutritive value of some browse and forb species. Proc. West. Sec. Amer. Soc. Anim. Sci. 26:160-162.

Cully, M.J. 1937. Grazing habits of range cattle. USDA Forest Serv. Res. Rep. Note 21. Southwestern Forest and Range Exp. Sta., Tucson, Ariz.

Doran, C.W. 1943. Activities and grazing habits of sheep on summer ranges. J. Forest. 41:253-258.

Fairchild, J.A., and J.D. Brotherson. 1980. Microhabitat relationship of six major shrubs in Navajo National Monument, Arizona. J. Range Manage. 33:150-156.

Fleming, C.E. 1920. Poisonous range plants. Nevada Agr. Exp. Sta., Ann. Rep. 1919:39.

Foster, L., J.L. Lantow, and C.P. Wilson. 1921. Chamiza as an emergency feed for range cattle. New Mexico Agr. Exp. Sta. Bull. No. 125.

Hansen, R.M., and I.K. Gold. 1977. Blacktail prairie dogs, desert cottontails and cattle trophic relations on shortgrass range. J. Range Manage. 30:210-214.

Hansen, R.M., D.G. Peden, and R.W. Rice. 1973. Discerned fragments in feces indicate diet overlap. J. Range Manage. 26:103-105.

Heady, H.F., and D.T. Torell. 1959. Forage preference exhibited by sheep with esophageal fistulas. J. Range Manage. 12:28-34.

Herbel, C.H., and A.B. Nelson. 1966. Species preferences of Hereford and Santa Gertrudis cattle on a southern New Mexico range. J. Range Manage. 19:177-181.

Hyder, D.N., R.E. Bement, E.E. Remmenga, and D.F. Hervey. 1975. Ecological respones of native plants and guidelines for management of shortgrass range. USDA Tech. Bull. 1503. 
Hyder, D.N., R.E. Bement, E.E. Remmenga, and C. Terwilliger, Jr 1966. Vegetation-soils and vegetation-grazing relations from frequency data. J. Range Manage. 19:11-17.

Johnson, M.K., H. Wofford, and H.A. Pearson. 1983. Microhistological techniques for food habits analyses. USDA Forest Serv. Res. Paper SO-199. Southern Forest Exp. Sta., New Orleans, La.

Kautz, J.E., and G.M. Van Dyne. 1978. Comparative analyses of diets of bison, cattle, sheep, and pronghorn antelope on shortgrass prairie in northeastern Colorado, U.S.A. p 438-443 In: D.N. Hyder (ed.) Proc. First Int. Rangeland Congr. (Aug. 14-18, 1978, Denver, Colo.) Soc. Range Manage., Denver, Colo.

Klipple, G.E., and D.F. Costello. 1960. Vegetation and cattle responses to different intensities of grazing on short-grass ranges on the Central Great Plains. USDA Tech. Bull. 1216.

Lesperance, A.L., P.T. Tueller, and V.R. Bohman. 1970. Symposium on pasture methods for maximum production in beef cattle: competitive use of the range forage resource. J. Anim. Sci. 30:115-121.

McInnis, M.L., M. Vavra, and W.C. Krueger. 1983. A comparison of four methods used to determine the diets of large herbivores. J. Range Manage. 36:302-306.

Monsen, S.B. 1980. Interseeding fourwing saltbush (Atriplex canescens (Pursch) Nutt.) with crested wheatgrass (Agropyron desertorum Schult.) on southern Idaho rangelands. Abstr., Soc. for Range Manage., 33rd Annual Meeting, San Diego, Calif.

NRC (National Research Council). 1984. Nutrient requirements of beef cattle. National Academy Press, Washington, D.C.

Prister, J.A., G.B. Donart, R.D. Pieper, J.D. Wallace, and E.E. Parker. 1984. Cattle diets under continuous and four-pasture, one-herd grazing systems in southcentral New Mexico. J. Range Manage. 37:50-54.

Pieper, R.D., C.W. Cook, and L.E. Herris. 1959. Effect of intensity of grazing upon nutritive content of the diet. J. Anim. Sci. 18:1031-1037.

Pieper, R.D., and G.B. Donart. 1978. Response of fourwing saltbush to periods of protection. J. Range Manage. 31:314-315.

Plummer, A.P., S.B. Monsen, and D.R. Christensen. 1966. Fourwing saltbush a shrub for future game ranges. Utah Div. Fish and Game Pub. No. 66-4.

Quinton, D.A. 1972. Standardization of the nylon bag technique and its use in nutritive evaluation of northeastern Colorado range sites. Ph.D. Diss. Colorado State Univ., Fort Collins.

Reppert, J.N. 1960. Forage preference and grazing habits of cattle at the Eastern Colorado Range Station. J. Range Manage. 13:38-65.

Rice, R.W., and M. Varra. 1970. Botanical species of plants eaten and intake of cattle and sheep grazing shortgrass prairie. U.S. Int. Biol. Program, Grassl. Biome Tech. Rep. 103. Colorado State Univ., Fort Collins.
Rosiere, R.E., R.R. Beck, and J.D. Wallace. 1975. Cattle diets on semidesert grassland: botanical composition. J. Range Manage. 28:89-93.

Rumbaugh, M.D., D.A. Johnson, and G.A. Van Epps. 1982. Forage yield and quality in a Great Basin shrub, grass and legume pasture experiment. J. Range Manage. 35:604-609.

SIms, P.L., and J.E. Taylor. 1973. Nutritive evaluation of important range forage plants for the shortgrass prairie in northcentral Colorado. Colorado State Univ. Exp. Sta. Prog. Rep. 73-70.

Sparks, D.R., and J.C. Malechek. 1968. Estimating percentage dry weight in diets using a microscope technique. J. Range Manage. 21:264-265.

Spatz, G. 1970. Pflanzengesellschaften, Leistungen and Leistungspotential von Allgauer Alpweiden in Abhangigkeit von Standort und Bewirtschaftung. Ph.D. Diss. Tech. Univ. Munich, West Germany. As cited in: Mueller-Dombois, D., and H. Ellenberg. 1974. Aims and methods of vegetation ecology. John Wiley and Sons, New York.

Springfield, H.W., and H.G. Reynolds. 1951. Grazing preferences of cattle for certain reseeding grasses. J. Range Manage. 4:83-87.

Streeter, C.L., D.C. Clanton, and O.E. Hoehne. 1968. Influence of advance in season on nutritive value of forage consumed by cattle grazing western Nebraska native range. Nebraska Agr. Exp. Sta. Res. Bull. 227.

Takatsuki, S. 1978. Precision of fecal analysis: A feeding experiment with penned sika deer. J. Mammal. Soc. Japan 7:167-180.

Thetford, F.0., R.D. Pieper, and A.B. Nelson. 1971. Botanical and chemical composition of cattle and sheep diets on pinyon-juniper grassland range. J. Range Manage. 24:425-431.

Trlica, M.J., M. Buwai, and J.W. Menke. 1977. Effects of rest following defoliations on the recovery of several range species. J. Range Manage. 30:21-27.

USDA-SCS. 1982. National list of scientific plant names. SCS TP-159. Washington, D.C.

USDA-SCS, Colorado. 1975-1983. Range site descriptions No. 2, 24, 36 , 56, and 63 for the Central High Plains (MLRS 67). Technical Guide, Section II E. Available from USDA-SCS, P.O. Box 17107, Denver, Colo.

Vavra, M., and J.L. Holechek. 1980. Factors influencing microhistological analysis of herbivore diets. J. Range Manage. 33:371-374.

Vavra, M., R.W. Rice, and R.M. Hansen. 1978. A comparison of esophageal fistual and fecal material to determine steer diets. J. Range Manage. 31:11-13.

Vavra, M., R.W. Rice, R.M. Hansen, and P.L. Sims. 1977. Food habits of cattle on shortgrass range in northcentral Colorado. J. Range Manage. 30:261-263.

Watkins, W.E. 1943. Composition of range grasses and browse at varying stages of maturity. New Mexico Agr. Exp. Sta. Tech. Bull. 311.

MOVING? Please try to give us four weeks notice. Send your present address label and this form to Society for Range Management

2760 W. 5 th Ave.

Denver, Colo. 80204

\author{
ATTACH OLD \\ ADDRESS LABEL \\ HERE
}

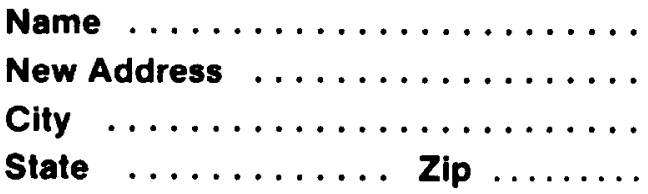

